\title{
Review on Current Status of Waste Electric and Electronic Product in Malaysia
}

\author{
Shafizan Jaibee ${ }^{1, a}$, Abd Khalil Abd Rahim ${ }^{1, b}$, Fariza Mohamad ${ }^{2, c}$, \\ Saifulnizan Jamian ${ }^{1, d}$, Sia Chee Kiong ${ }^{1, e}$, Yokoyama Seiji ${ }^{2, f}$, \\ Nik Hisyamudin Muhd Nor ${ }^{1, g}$ \\ ${ }^{1}$ Engineering Design Research Group (EDRG), Department of Material and Design Engineering, \\ Faculty of Mechanical and Manufacturing Engineering, Universiti Tun Hussein Onn Malaysia, \\ 86400, Parit Raja, Batu Pahat, Johor, Malaysia. \\ ${ }^{2}$ Department of Mechanical Engineering, Toyohashi University of Technology, 1-1 \\ HibarigaokaTenpaku Toyohashi Aichi Japan. \\ ahd130111@siswa.uthm.edu.my, bkhalil@uthm.edu.my, ${ }^{c}$ farizamd@uthm.edu.my, \\ dsaifulnz@uthm.edu.my, ${ }^{\mathrm{e}}$ sia@uthm.edu.my, ${ }^{\mathrm{e}}$ yokoyama@me.tut.ac.jp, fnhisyam@uthm.edu.my
}

Keywords: E-waste, electric and electronic waste management, recycling.

\begin{abstract}
In the last years, there is an increasing acknowledgment of our impact on the environment due to our lifestyle, while the need to adopt a more sustainable approach as to our consumption habits emerges as of particular significance. This trend regards industrial sectors affecting the consumption habits and, especially, electronic industry where the short life cycles and the rapidly developing technology have led to increased e-waste volumes, such as discarded electronic equipment. Waste Electric and Electronic Product or E-waste is referred to all kind of electric and electronic equipments and appliances that are thrown by users. The majority of such elements result in landfills because it is inexpensive disposal option. The E-waste has become a matter of concern because of toxic and hazardous present in electronic goods and if not properly managed. This equipments are a complicated assembly of thousand material, many of which one highly toxic such as brominates substances, toxic gases, toxic metals, biologically active material, acids, plastics and plastics additives. However, their partial recyclability, due to their material composition along with the unavoidable restrictions in landfills, has led to the development of retrieval techniques for their recycling and re-use, highlighting the significance of e-waste recycling, not only from a waste management aspect but also from a valuable materials' retrieval aspect. This paper provides an overview of E-waste generation and management in Malaysia, which, with rapid economic growth and urbanization, is becoming a major social and environmental issue. Thus, major concern for Ewaste management in Malaysia has addressed to environmental protection, compared to quantity control. The challenge now is to make the practice effectively in the many different contexts in Malaysia.
\end{abstract}

\section{Introduction}

E-waste is a short form of electrical and electronic waste, also known as electronic waste or waste of electrical and electronic equipment (WEEE), this term is used to describe an electrical and electronic equipment (EEE) that had obsolete or end of life (EOL) [1]. There is no generally accepted definition of e-waste around the world. However, e-waste is often misunderstood as classified only computer and related IT equipment [2]. It is universally understood as disposed of electronic wastes by their consumers and these include a wide range of products, from simple design to complex devices [3].

E-waste has been categorized into three main categories, Large Household Appliances such as refrigerator and washing machine, IT and Telecom such as PC, monitor and laptop and Consumer Equipment such as television and DVD player [4]. E-waste commonly comes from various resources [5]: 1. Residue or leftover materials from electronic products manufacturing process; 2. 
Leftover parts or materials, or discarded electrical and electronic equipment generated from a repair shop; 3. Obsolete electrical and electronic equipment coming from governments, companies, and other facilities; 4. Obsolete electrical or electronic products mainly from households; 5. Obsolete electrical or electronic products brought in by smuggling.

In the total e-waste flow, electronic IT category equipments contribute to a greater extent compared to other categories because of their short life cycle with average of 3 years compare to the household equipments that having an average life cycle of 10-12 years [6]. Fig. 1 shows some examples of e-waste found in Malaysia landfill areas. Component of e-waste is very diverse and differs between electrical and electric products which may contain more than thousand different substances, which may fall either under hazardous or non-hazardous types [7]. But, many substances contained in e-waste are considered hazardous waste [8].

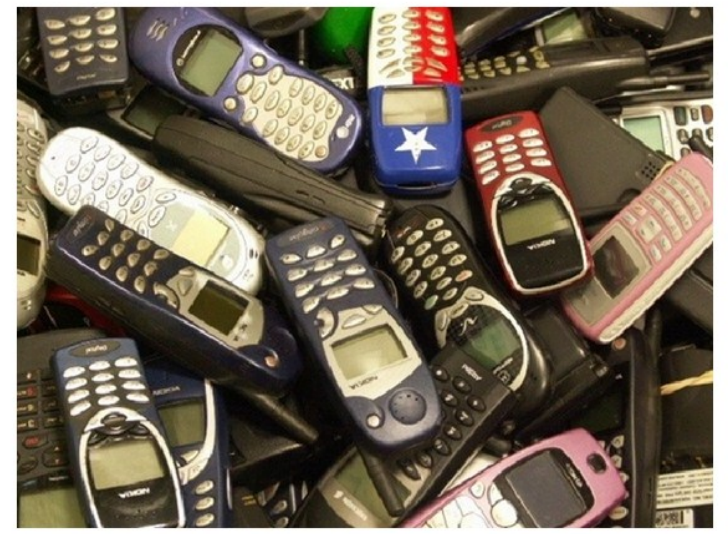

(a)

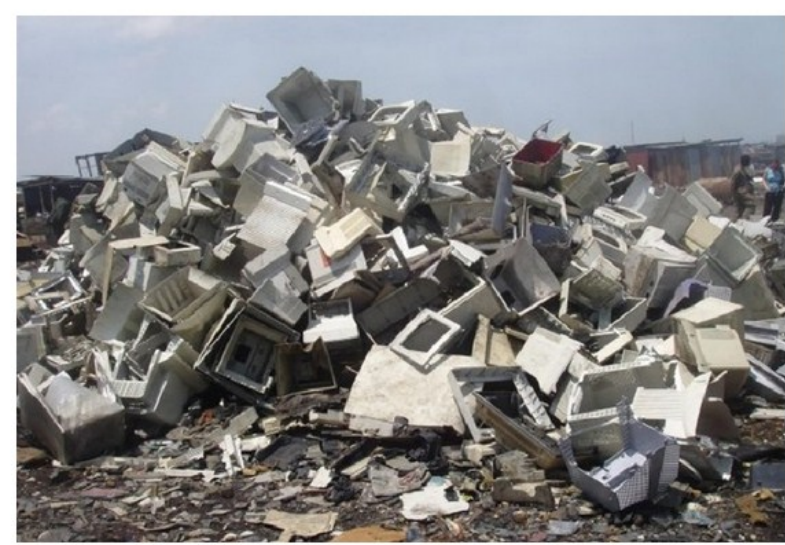

(b)

Fig. 1 Example of e-waste in Category 3 (ICT): (a) used mobile phones and (b) used monitors.

In production of electronic and electrical appliances, there are many sources that been used, it can be either natural or synthetic materials. For example, for proposes of manufacturing of electronic equipment metal such chromium which is naturally occurring substance is relatively harmless in nature [10]. However, with improper disposal it becomes harmful due to its toxicity that can affect human health and the environment [11]. With combination of these substances, together with smelting and burning of waste, causes local air pollution and activities from acid bath stripping will contaminate ground and surface water [10]. These toxins also pose potential health problems including lung disease, lead poisoning and cancer.

\section{Production of E-waste}

The quantities of e-waste generated in Malaysia according to the Environment Quality Report by DOE shown in Fig. 2. These amounts of e-waste generated from 2006 to 2011. As shown, the quantities of e-waste are slightly increases year by year. This is caused by the rapid increased of the EEE amount produced and imported into Malaysia as well as the increase of development of a growing its technology. 


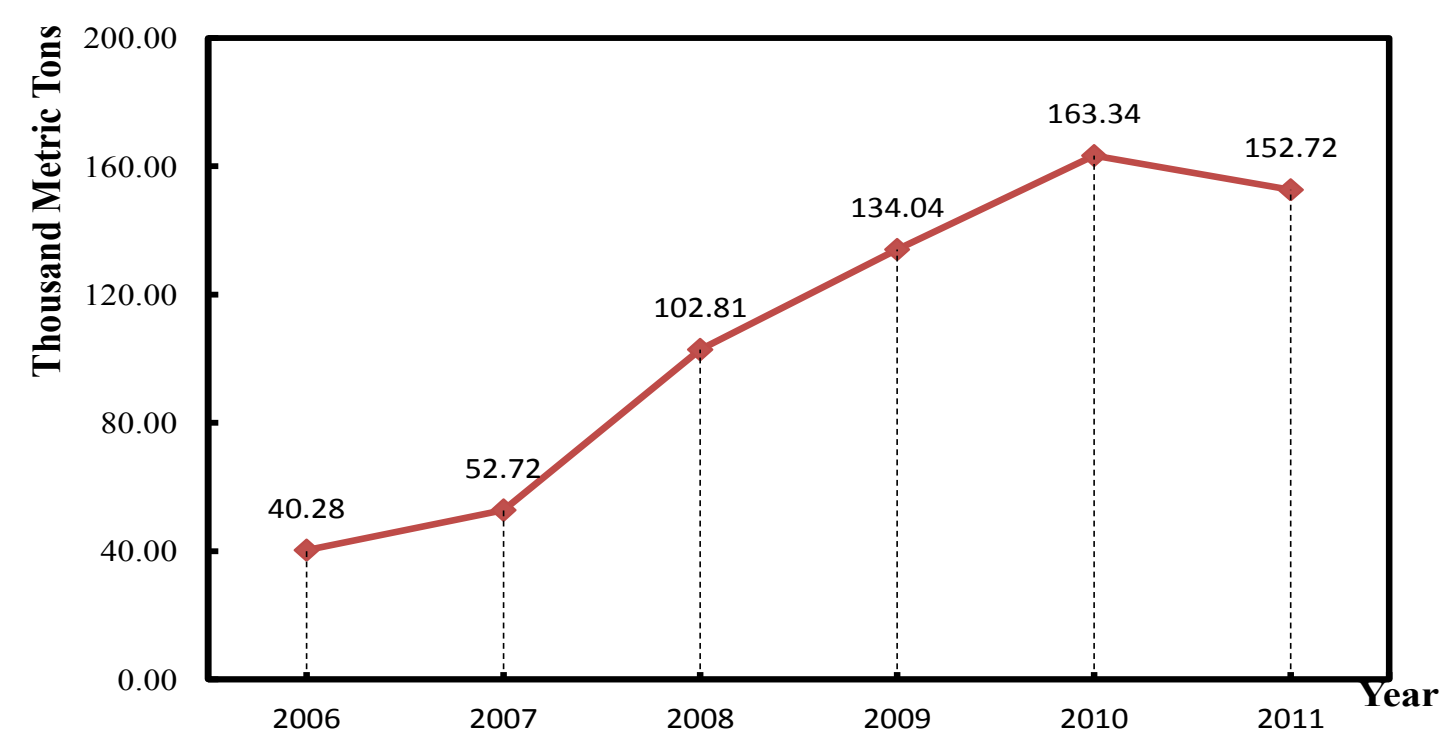

Fig. 2 Quantity E-waste (code SW 110) generated in 2004-2011 [12]

\section{E-waste Composition}

E-waste contains precious materials such as silver and gold, hazardous material such as cadmium, chromium, lead and mercury, and also non-ferrous metals such as aluminum and cooper. If the hazardous compounds in e-waste not recycle properly, it will bring a serious impact to human health and environment. In the electronic devices, the mainly components that made from toxic metals and chemicals are such as chromium, mercury, cadmium, lead, beryllium, phthalates, polyvinyl chlorides (PVC), brominated flame-retardants and antimony. Exposure in long term to these substances can damages the physiological system in human body such as endocrine system, reproductive system and nervous system. Currently, most of these devices end up in landfill sites with no proper treatment because of the lack of segregation mechanism. Furthermore, over that $90 \%$ of these wastes were sending to the landfill while in other countries, a large fraction of these wastes from households end up in the waste incinerators [4]. From this melting or unscientific burning of computer chips, the acids and sludge that obtained and when it disposed on to the ground can causes soil acidification, leads to contamination of the water sources.

When e-waste has been incinerated, the toxic fumes will produce pollution to the ambient air. Non-proper recovering and recycling methods can gives major impact on the environment and can affect to our health. Crude forms from dismantling are often expose the employees to the harmful substances as most of the employees are not aware of the effects of the detrimental substances in these wastes to their health and also as they do not wear protective equipment [4]. The toxic compounds in the materials that present in the equipment can be health as well as environmental hazards. Mercury for example, will leach when certain electronic device such as circuit breakers are destroyed. Furthermore, the leaching of mercury induces problems, the vaporization of methylene mercury and metallic mercury is also a huge concern [4]. Because of lack of facilities, improper waste management and value recovery methods not exist for managing the waste, the wastes are imported from developed countries to developing countries is created [5]. Fig. 3 shows the average composition of material in e-waste. It was found that the main compositions of e-waste are plastics, copper, refractory oxides and iron. 


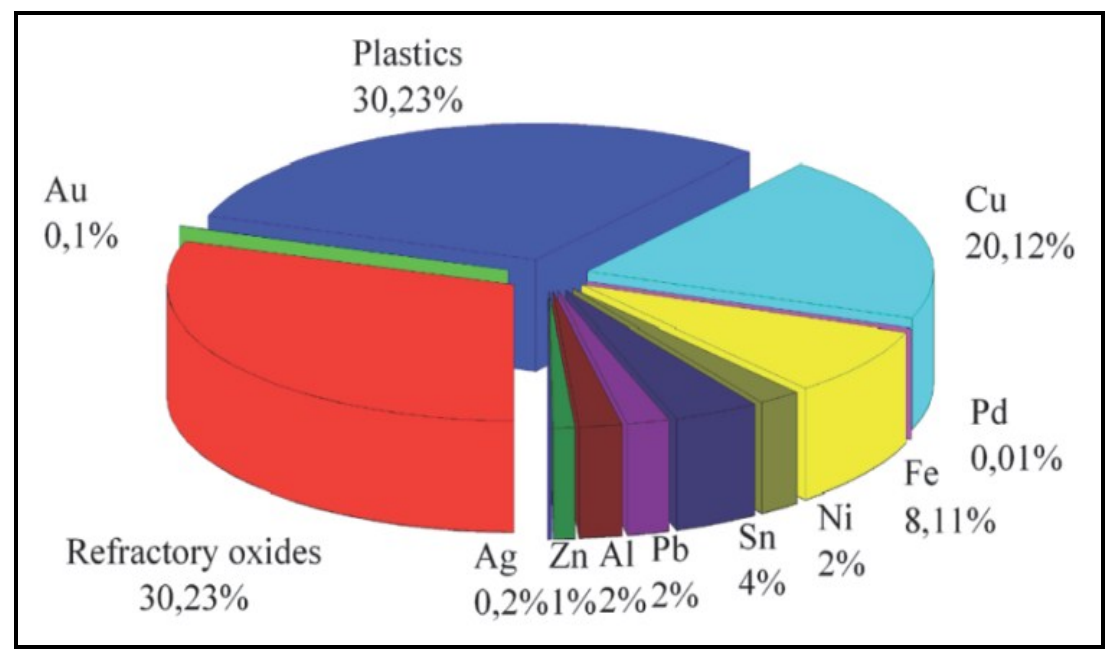

Fig. 3 Average composition of e-waste.

\section{E-waste regulations}

In Malaysia, all environmental issues are controlled by the Department of Environment (DOE) under the Ministry of Natural Resources and Environment (NRE) [13]. Through the enforcement of the Environmental Quality Act 1974 (EQA 1974), the main roles of DOE are to prevent, control and abate pollution in Malaysia. Under EQA 1974, the Environmental Quality (Scheduled Wastes) Regulation 1989 (EQSWR 1989) was regulated. These regulations were based on the cradle to grave concept where the generation, storage, transportation, treatment and disposal of wastes are regulated. In 15 August 2005, the scheduled wastes are categorized based on the type of waste rather than the source or origin of the waste. This Environmental Quality (Scheduled Wastes) Regulations 2005 (EQSWR 2005) are enforced to replace the EQSWR 1989 [14].

With these regulations, E-waste is categorized under SW110 in the First Schedule of EQSWR 2005 [13]. However, these Regulations do not directly deal with e-waste that came from households. Before year 2005, DOE was not recognized e-waste as waste that can bring bad effects to human's body and the environment. After e-waste analyzed and discovered that it containing hazardous substances such as lead, cadmium and mercury, it has become an issue because of its inappropriate system of management. With the enforcement of EQSWR 2005, e-waste is not allowed to dispose by any person into landfills [3]. The wastes shall be recycled and recovered at prescribed or licensed premises while disposal must take place at prescribed premises only and must be carried out in an environmentally sound manner [9].

A set of guidelines known as the Guidelines for the Classification of Used Electrical and Electronic Equipment, has been issued by DOE. The scope of E-waste in these guidelines is to assist parties such as waste generators, waste importers or exporters and relevant authorities involved. These guidelines were issued in January 2008 and they have identified the different categories of Ewaste and specified the characteristics of E-waste. Currently, this guideline only distinguishes between E-waste and non E-waste. These also specify the criteria for the import and export of used electrical and electronic equipment or components that are not categorized as E-waste. Waste categorized as E-waste is not allowed to be imported without approval from the Basel Convention.

There are two main types of E-waste generators mentioned in these guidelines but only from the industries is managed well. These guidelines do not provide any information on how users in Malaysia should manage their e-waste at the end of the product's lifespan. Essentially, these guidelines could have served as an information tool to inform electrical and electronic consumers on how to identify which product qualifies as E-waste and which does not. In addition to this, the guidelines could also present the government with alternatives on how to achieve higher levels of reuse and recycling of E-waste, and ultimately to reduce the generation of E-waste [15]. 


\section{E-waste management}

Usually users do not immediately discard or recycle unused electronics since they think that the products still retain some value [3]. According to USEPA (2000), more than 70\% of retired CEDs are kept in storage for 35 years [16]. The fact that the storage method was chosen rather than the disposal or reuse of the old technology is a crucial factor. This highlights lack of awareness on where to dispose of old technology and psychological factors such as belief that e-waste has some value [3].

Table 1 Distribution of e-waste recovery facilities in Malaysia [12]

\begin{tabular}{lcc}
\hline State & Partial recovery facility & Full recovery facility \\
\hline Johor & 17 & 3 \\
Kedah & 12 & 1 \\
Melaka & 12 & 3 \\
Negeri Sembilan & 5 & 1 \\
Perak & 4 & 0 \\
Pulau Pinang & 37 & 6 \\
Sarawak & 5 & 0 \\
Selangor & 25 & 2 \\
Wilayah Persekutuan & 5 & 0 \\
\hline Total & 122 & 16 \\
\hline Grand total & & \\
\hline
\end{tabular}

There is already a proper management of e-wastes generated from industries. Industries can send their e-wastes to the recovery facilities licensed by the DOE. In Malaysia, there are 138 e-waste recovery facilities currently as shown in Table 1 . Only 16 out of the facilities are for the full recovery and others are the facilities for partial recovery [12]. However, the main technology employed to e-wastes recovery in terms of precious metals is still limited to electrolysis and wet chemical processes [17]. Currently all of the e-wastes recovery facilities in Malaysia are built and operated by private companies [18]. Generally the industries or e-waste generators will be paid by the e-waste recovery facilities when they send the supply of e-wastes to the facilities [19].

The Department has conducted co-operations with the National Solid Waste Management Department (NSWMD) on how to collect the e-wastes from the residential areas effectively [21]. For a start the public users can send their e-waste to the e-waste collection centers that addressed in the DOE's website. These collected wastes are limited to used mobile phones, mobile phone's batteries and their accessories, computers and their accessories, as well as television sets [12]. These collection centers are currently managed by the solid waste concessionaires or local authorities [19]. E-waste management flow chart in Malaysia from both industries and household is shown in Fig. 4 and Fig. 5 shows the detail of household E-waste management.

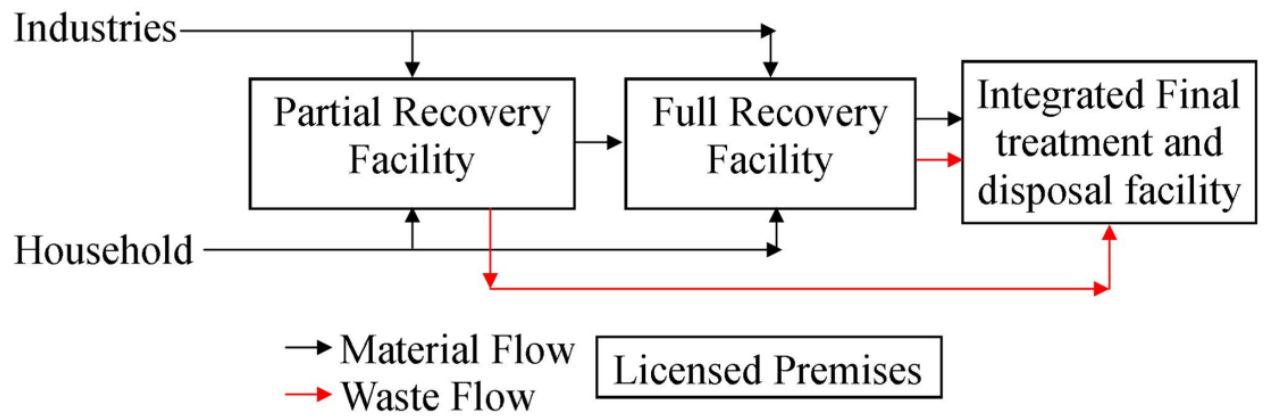

Fig. 4 Flow chart of E-waste management generally. 


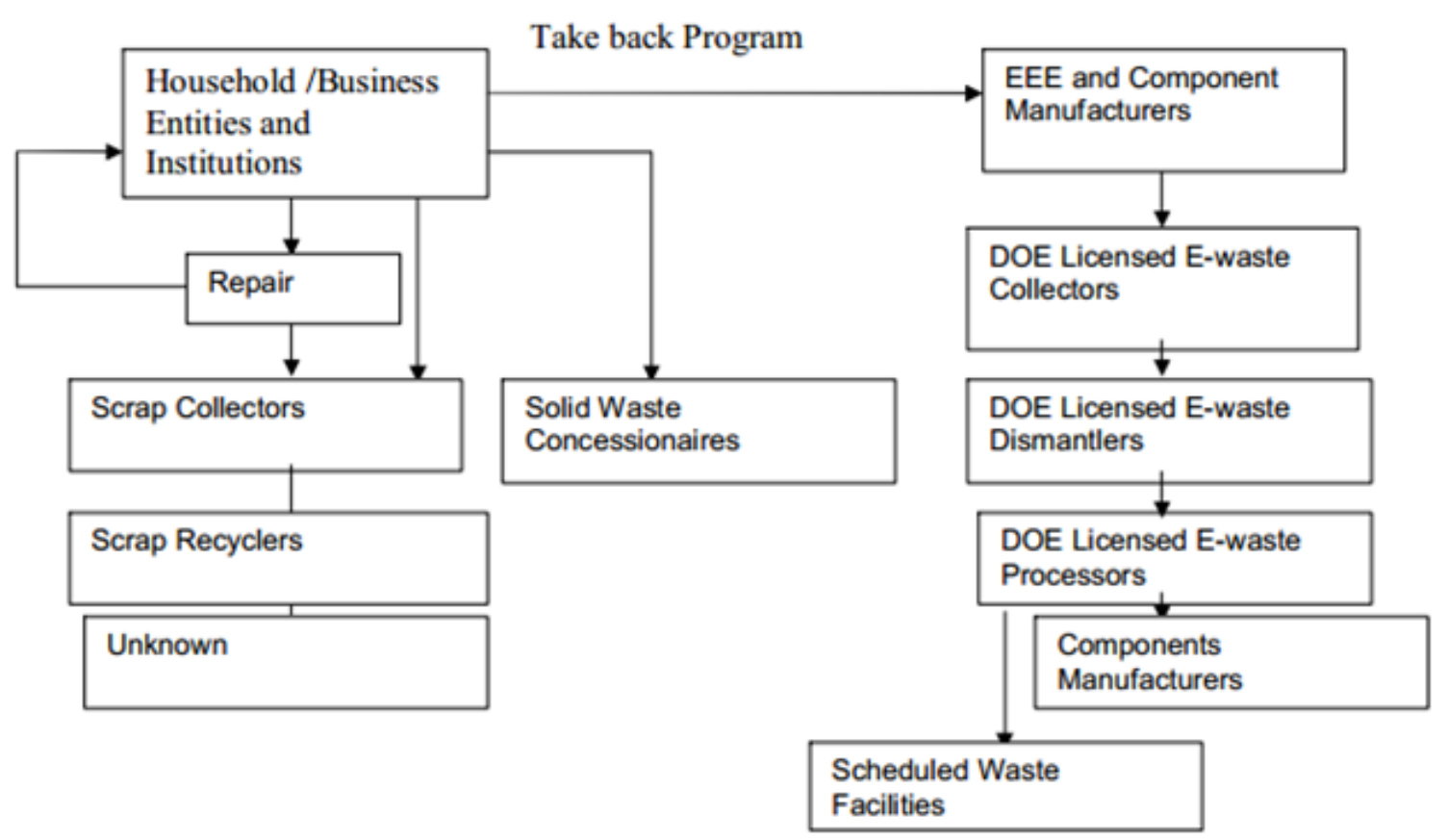

Fig. 5 Flow of WEEE from Generation to Disposal. [21]

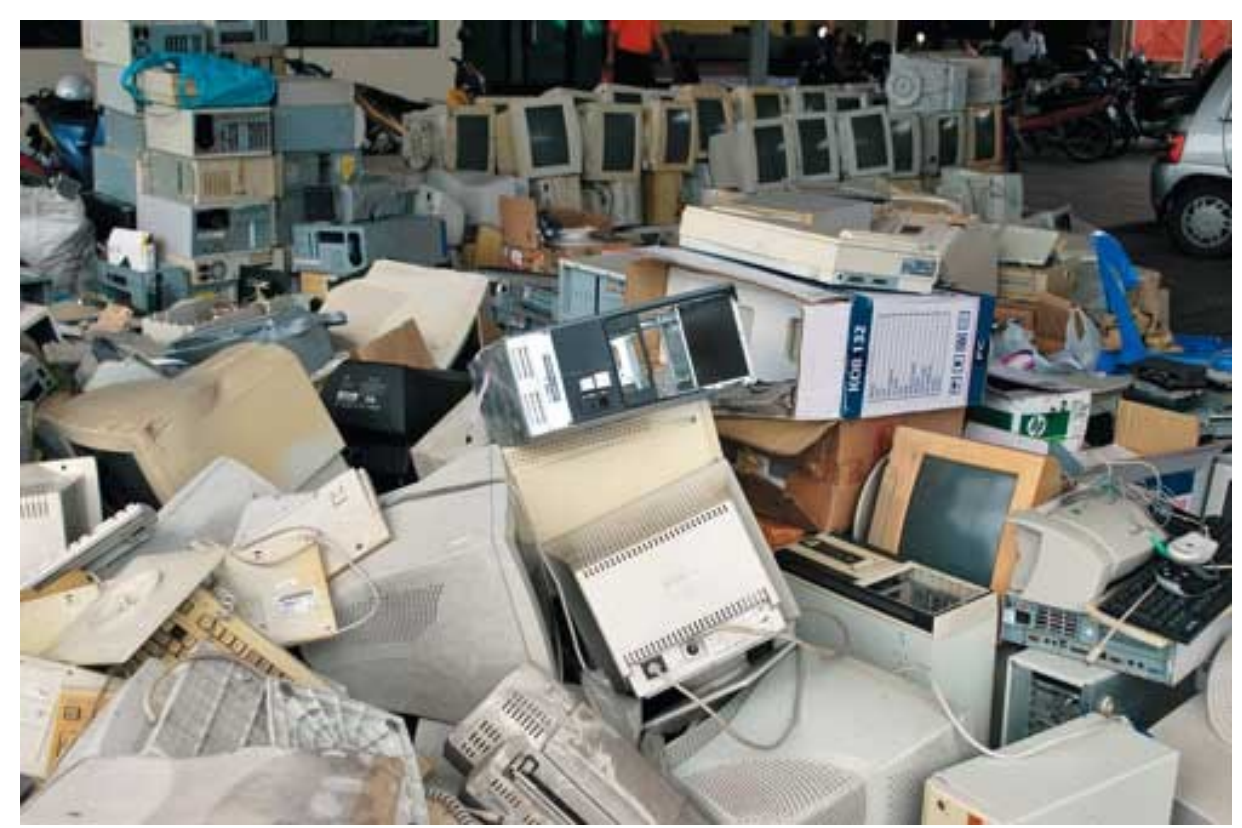

Fig. 6 E-waste collection in one of the collecting center in Malaysia.

\section{Technology related to E-waste recycling}

The important steps in recovery of E-waste are dissolving, separate and collect. There are many methods to dissolving and the most popular method is leaching using sulfuric acid. Even though there are many method in dissolving, as an engineer we should find the best methods by considering the parameters such as temperature, particle size, pouring density and so on. First step in recycling process is manual dismantling, which enable the recovery of whole homogenous parts that may will be valuable, recyclable or reusable, such as whole components, plastic, glass or metal parts, and hazardous component that require further special treatment, such as batteries, waste motor, mercury containing components, LCD and CRT-glass [19, 20]. Further liberation and size reduction of the recyclable materials, such as PCBs, is usually achieved by some kind of crushing process or shredding [21]. Typical recycling process can be seen in Fig. 7. 


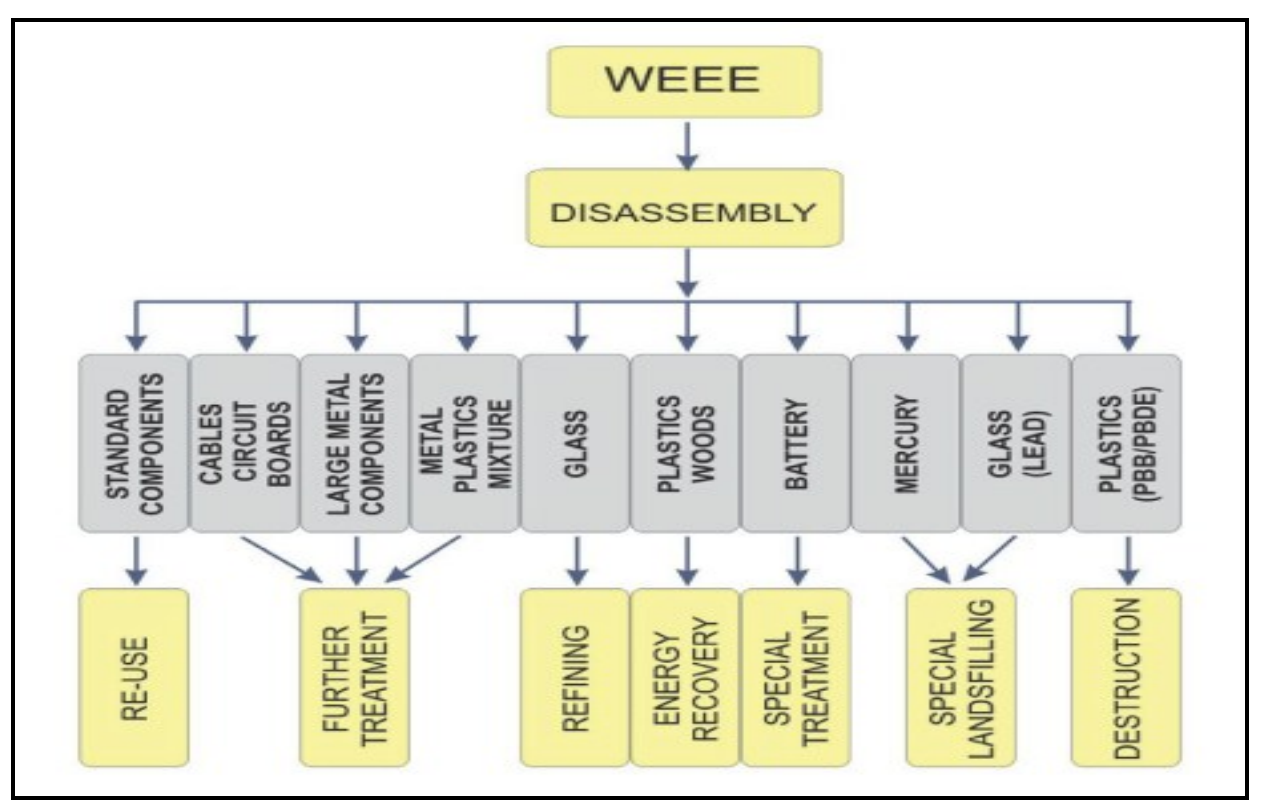

Fig. 7 Typical recycling process

After the size has been reduced, the material are sorted into defined output fractions based on their specific physical characteristic, such as size, weight, density, shape, as well as magnetic and electrical characteristic. Normally shorting process used are magnetic separation of ferrous parts, screening, eddy current separation (electric conductivity) of non-ferrous metals such as aluminum and copper, and gravity or density separation (water and airflow table, sifting, heavy mediafloating) of plastic. After that, metallurgical processes are performed to upgrading and refining of metal containing fraction. Both pyrometallurgical process in which the metals are melted, and hydrometallurgical processes which the metals are dissolved, reused and often in combination [21]. In the last two decades, Pyrometallurgical processes in copper smelters followed by electrolytic refining has become the regular method to recover non-ferrous metals, precious metal and also other valuable metals, from the e-waste [22]. The main step in hydrometallurgical processes are consist of a series of acid or caustic leaching of solid material, which typically requires a small grain size to increase the yield of metals [21].

\section{Issues in E-waste in Malaysia}

Electronic and electric device are commonly made from many types of components, some of the components containing toxic substances that can gives effect to environment and human health if not properly handled. Frequently, these hazards appear due to the use of not proper disposal and recycling processes. It can have serious repercussions for those in proximity to places where e-waste is recycled or burnt. Waste from the white and brown goods is less toxic as compared with grey goods. Generally, a computer contains highly toxic chemicals like cadmium, lead, mercury, BFR, beryllium, phosphor and polyvinyl chloride compounds. Table 1 shows the environment and health hazards effect from the E-waste. In the E-waste in the computer category, there is many hazard materials such as Lead, Mercury, Cadmium and PAH (Polycyclic Aromatic Hydrocarbons) [17]. These hazard materials can affect the environment and our body. 
Table 2 Hazardous material effect in e-waste [17,18]

Compound Location Effect

Lead $\begin{gathered}\text { Soldering of PCB and } \\ \text { other electronic } \\ \text { components }\end{gathered}$
.

\begin{tabular}{l|l} 
Mercury & Batteries, switch/housing \\
and printed wiring board.
\end{tabular}

Cadmium
Can affect various systems in the body such as the peripheral nervous systems and central, hemopoietic system and reproductive systems.

Can causes damage to the genitourinary system, the peripheral nervous systems and fetus as well as the central.

\begin{tabular}{l|cc}
\hline \multicolumn{3}{|c|}{ semi-conductors } \\
\hline $\begin{array}{l}\text { Plastics including } \\
\text { PVC }\end{array}$ & Cabling and housing Causes or aggravates asthma/bronchitis and \\
\end{tabular}

Brominated flame Plastic housing of EEE retardants $(\mathrm{BFR})$ and circuit board
Toxic from cadmium compounds collects in the human body, particularly in the kidneys.

DNA damage.

Currently, there is no mechanism on a proper segregation or disposal system to encourage the public to recycle and discard their e-waste. Continued generation of e-waste over time, together with lack of structured mechanisms of institutional framework and inadequate infrastructure, results in improper e-waste management. Even though at present electrical or electronic appliances are rarely disposed of indiscriminately, with little regulation in place this has created hazards to the local population as well as the environment [14].

The level of awareness of the hazardous compounds in E-waste is very low in Malaysia [10]. The consumer awareness of hazardous household waste constituting an environmental problem has sometimes been rather limited. The stakeholders thought that the hazardous waste ought to be sorted out, but several of them found that it was an issue that they had so far not considered. Of the same reason most of them had not considered how their institution or company might be part of this future system themselves [23]. Issue of financing is also one of the biggest obstacles, most of the consumers currently unwilling to pay for environmental costs related to household waste [3].

\section{Conclusion}

Although Malaysia has a specific law governing both municipal wastes and scheduled wastes, the related regulations and guidelines that directly deal with e-waste are not yet well established. These regulations mostly focus on the practices of E-waste management by industries. Awareness on ewaste has increased in the industrial management context and this can be seen from 2005 when ewaste was first introduced in EQSWR 2005. However, the level of public awareness is still low as people are still disposing E-waste same as other household wastes, storing E-waste in their premises, and giving E-waste to scrap collectors.

Malaysia can learn from other developed countries such as United State and Japan about their management of E-waste. Several techniques and technologies can be adapted to improve the existing E-waste management in Malaysia. If Malaysia can implement better technology, E-waste 
recycling could be industry that can enhance the development of this country and able to provide a lot of employment opportunities for Malaysians. Therefore, research and studies regarding of Ewaste recycling and management are required to overcome this problem.

\section{Acknowledgements}

This work is financially supported by the Research Acculturation Grant Scheme (RAGS) under the Ministry of Higher Education Malaysia. Authors also want to thank Office for Research, Innovation, Commercialization, Consultancy Management (ORICC) UTHM that always give full assistance and support in this project.

\section{Reference}

[1] Y. C. Jang and H. Yoon, The Practice and Challenges of Electronic Waste, Recycling in Korea with Emphasis on Extended Producer Responsibility (EPR). (2006)

[2] S. Jain, K. Mohan Garg, Managing E-Waste in India: Adoption of Need Based Solutions, Journal of Internet Banking and Commerce 16 (3) (2011) 1-11.

[3] J. Ahmad Kalana, Electrical and electronic Waste Management practice by Household in Shah Alam, Selangor, Malaysia, International Journal of Environmental Sciences 1(2) (2010) 132-144.

[4] V. N. Pinto, E-waste hazard: The impending challenge, Indian Journal of Occupation and Environmental Medicine 12920 (2008) 67-70.

[5] Xuefeng Wen; Xiaohua Zhou; Hualong Hu, The new process in integrated e-waste management in China, ISEE 2008, 1-6.

[6] G. Gaidajis, K. Angelakoglou and D. Aktsoglou, E-waste: Environmental Problems and Current Management, Journal of Engineering Science and Technology Review 3 (1) (2010) 193199.

[7] B. V. GOPAL, Seminar Report on E-Waste Management, College Of Engineering Trivandru. (2010)

[8] L. Ecroignard, E-waste legislation in South Africa, eWASA, engineerIT. (2006)

[9] F. Suja, R. Abdul Rahman, A. Yusof, and M. S. Masdar, E-Waste Management Scenarios in Malaysia, Journal of Waste Management, Volume 2014 (2014), Article ID 609169, 1-7.

[10] Attention on Commercial E-waste in Putrajaya an Environmental Sciences Essay, Information on: http://www.ukessays.com/essays/sciences/attention-on-commercial-e-waste-in-putrajaya-anenvironmental-sciences-essay.php\#ixzz3HPuw4Eum

[11] Hazardous Substances in E-waste, Information on http://ewasteguide.info/node/219.

[12]A. R. Awang, E-waste Management in Malaysia, DOE Malaysia, Information on: http://Gec.Jp/Gec/Jp/Activities/Ietc/Fy2010/E-Waste/Ew_1-4.Pdf.

[13]A. Memon, Devolution of Environmental Regulation: EIA in Malaysia, UNEP EIA TrainingResource Manual.

[14] Waste Engineering, Lembaga Jurutera Malaysia, The Ingenieur, KDN PP11720/1/2008 ISSN 0128-4347, Volume 34. (2008)

[15] Guidelines for the Classification of Used Electrical and Electronic Equipment in Malaysia, DOE Malaysia. (2008)

[16]A. Jain and R. Sareen, E-waste Assessment Methodology and Validation in India, Journal of Material Cycles and Waste Management, Volume 8, Number 1/March. (2006) 
[17] H. Ghazali, Mapping Needs and Activities on Waste Management, Asia Pacific Workshop on Global Partnership on Waste Management, DOE Malaysia.

[18]R. Afroz , M. M. Masud, R. Akhtar, J. Duasa, Survey and Analysis of Public Knowledge, Awareness and Willingness to Pay in Kuala Lumpur, Malaysia - a Case Study on Household WEEE Management, Journal of Cleaner Production 52 (2013) 185 - 19.

[19] Current practice of recycling and treatment of hazardous wastes in Malaysia, DOE Malaysia, Information on: http://www.env.go.jp/en/recycle/asian_net/Annual_Workshops/2012_PDF/D1S24\%5BMALAYSIA\%5Drev.pdf

[20] Muhd Nor, N.H., Nathan, T., Jaibee, S., Burhan, M.H., Mohamad, F., Ismail, A.E., Kiong, S.C., Ahmad, Z., Yokoyama, S., Feasibility study of waste motor recycling through manual dismantling and hydrometallurgical process (2014) Key Engineering Materials, 594-595, pp. 990995.

[21]N. Ab Halim, E-waste Management in Malaysia, Country Presentation - Malaysia, DOE Putrajaya, Malaysia.

[22] Control of Trans Boundary Movement of Hazardous Wastes in Malaysia, DOE Malaysia, Information on: http://www.env.go.jp/en/recycle/asian_net/Annual_Workshops/2012_PDF/D1S12\%5BMALAYSIA\%5Drev.pdf

[23]P. Gatke, Future Management of Hazardous Household Waste in Petaling Jaya, Roskilde University Centre. (2003) 